\title{
Evaluation of chocolate as a source of dietary copper
}

\section{Thomas Weber \& Marc Solioz}

\author{
European Food Research and \\ Technology \\ Zeitschrift für Lebensmittel- \\ Untersuchung und -Forschung A \\ ISSN 1438-2377 \\ Volume 238 \\ Number 6 \\ Eur Food Res Technol (2014) \\ 238:1063-1066 \\ DOI 10.1007/s00217-014-2240-x
}

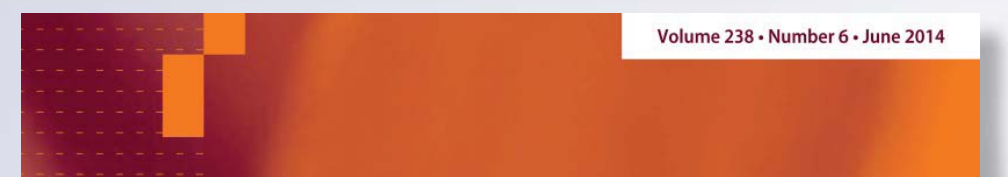

\section{European Food Research \& Technology}


Your article is protected by copyright and all rights are held exclusively by SpringerVerlag Berlin Heidelberg. This e-offprint is for personal use only and shall not be selfarchived in electronic repositories. If you wish to self-archive your article, please use the accepted manuscript version for posting on your own website. You may further deposit the accepted manuscript version in any repository, provided it is only made publicly available 12 months after official publication or later and provided acknowledgement is given to the original source of publication and a link is inserted to the published article on Springer's website. The link must be accompanied by the following text: "The final publication is available at link.springer.com". 


\title{
Evaluation of chocolate as a source of dietary copper
}

\author{
Thomas Weber $\cdot$ Marc Solioz
}

Received: 4 February 2014 / Revised: 14 April 2014 / Accepted: 28 April 2014 / Published online: 10 May 2014

(C) Springer-Verlag Berlin Heidelberg 2014

\begin{abstract}
Chocolate has frequently been proposed to be a valuable source of dietary copper, but data on the copper content of major contemporary chocolate brands are scarce. The copper content of 22 brands of chocolate, many of which are sold worldwide, is thus presented here. A reliable hot ashing procedure to determine the copper content of chocolate by inductively coupled plasma atomic emission spectroscopy is also described. It was found that the copper contents of the chocolates analyzed here varied in the range of $1.85 \pm 0.10$ to $16.50 \pm 1.29 \mu \mathrm{g} / \mathrm{g}$. There was a linear correlation of the copper content of chocolate to its cocoa content with a correlation coefficient $R^{2}$ of 0.89 , showing that the copper was largely contributed to the chocolate by the cocoa. The value of chocolate as a source of dietary copper is discussed.
\end{abstract}

Keywords Chocolate - Copper content · Nutrition · Deficiency

\section{Introduction}

Copper is an essential micronutrient and functions as a cofactor in over 30 enzymes in humans. The latest dietary reference intakes (DRI) for copper range form $0.5 \mathrm{~g} / \mathrm{day}$ for infants to $1.3 \mathrm{mg} /$ day for lactating women, with $0.9 \mathrm{mg}$ /

T. Weber $\cdot$ M. Solioz $(\bowtie)$

Department Clinical Research, University of Bern, Murtenstrasse 35, 3010 Berne, Switzerland

e-mail: marc@solioz-scientific.ch

\section{Solioz}

Department of Plant Physiology and Biotechnology, Tomsk State University, Prospect Lenina 36, 634050 Tomsk, Russian Federation day recommended for grown-up, healthy adults [1]. Copper intake beyond the DRI should probably be of no concern for healthy adults. According to a recent study, a copper intake of up to $8 \mathrm{mg}$ /day for 6 months did not appear to have any adverse effects in healthy individuals [2]. There are, however, conditions in which excessive copper intake may pose a risk, such as for individuals with Wilson disease, a genetic defect in copper secretion [24].

There is considerable debate of whether the DRI levels are sufficient and in fact, recommendations for adults in the United Kingdom, the European Community, and Australia/ New Zealand are higher and range from 1.1 to $1.2 \mathrm{mg} /$ day. The required copper intake may vary a great deal depending on the source of the copper and the nutritional context, both of which can affect the bioavailability (bioaccessibility) of the copper [3]. The focus in establishing nutritional guidelines for copper and maximal tolerable copper levels in drinking water has traditionally been placed on toxicity rather than essentiality. Currently, there is concern that some populations may be copper deficient and this problem may be exacerbated in special circumstances, such as in disease or following bariatric surgery, which is dramatically on the rise [4-8].

The copper content of food varies over a wide range. It is lowest in fats and oils, dairy products, sugar, tuna, and lettuce $(<0.4 \mu \mathrm{g} / \mathrm{g})$. Higher copper levels are present in legumes, mushrooms, chocolate, nuts, and seeds $(>2.4 \mu \mathrm{g} / \mathrm{g})$. The best sources of copper are beef liver and oysters, which typically contain $70-200 \mu \mathrm{g} / \mathrm{g}$ of copper $[9,10]$. With the increasing awareness in nutrition, particularly in the Western world, people frequently turn to Internet sites for information on nutritional aspects. As a good nutritional source of copper, chocolate is often being recommended (e.g., http://www.healthaliciousness.com/articles/high-copperfoods.php). On the other hand, liver and oysters are absent 
in many recommendations for copper-rich foods, probably due to the lack of tradition of eating these foods in some countries.

Due to a lack of data on the copper content of contemporary chocolates, we here determined the copper content of 22 major brands of chocolate by dry ashing and inductively coupled plasma atomic emission spectroscopy (ICPAES). It was found that the copper content linearly correlated with the cocoa content. Thus, cocoa-rich chocolates should be recommended if chocolate is to serve as a source of dietary copper.

\section{Materials and methods}

Different brands of chocolate were bought in local shops and supermarkets in Berne, Switzerland, and stored at room temperature. The cocoa content was taken either from the product label or was inquired at the manufacturer. For copper measurements, samples of 1-1.5 g of chocolate were ashed in a kiln at $400{ }^{\circ} \mathrm{C}$ for $3 \mathrm{~h}$ and at $600{ }^{\circ} \mathrm{C}$ for 14 h. Fused silica crucibles $\left(99.7 \% \mathrm{Al}_{2} \mathrm{O}_{3}\right.$, Alsint, Faust Laborbedarf AG, Schaffhausen, Switzerland) rather than ceramic crucibles had to be used. Extensive experiments in our laboratory had shown that standard ceramic crucibles were unsuitable as they absorbed variable amounts of copper, depending on the history of the crucibles. After cooling of the ashed samples, the residues were dissolved in $1 \mathrm{ml}$ of $67 \% \mathrm{HNO}_{3}$ for $1 \mathrm{~h}$ under agitation. After addition of $1 \mathrm{ml}$ of $30 \% \mathrm{H}_{2} \mathrm{O}_{2}$ and further incubation for $1 \mathrm{~h}$ at room temperature, the sample was brought to a final volume of $6 \mathrm{ml}$ with water. This resulted in a clear solution without insoluble residues. Copper concentrations were measured by ICP-AES, using a Jobin-Yvon JY 24 instrument (HORIBA Jobin-Yvon GmbH, Munich, Germany) at a wavelength of $324.754 \mathrm{~nm}$ and using Gauss integration for $0.5 \mathrm{~min}$. The lower limit of detection for copper was five parts per billion.

\section{Results}

A number of published methods were assessed in their reliability to measure copper in chocolate. It was found that published wet ashing procedures in mixtures of concentrated $\mathrm{HNO}_{3}$ and $\mathrm{H}_{2} \mathrm{O}_{2}$, or dry ashing at $500{ }^{\circ} \mathrm{C}$ gave poor reproducibility across chocolates with widely differing cocoa and fat contents $[11,12]$. These published methods had been evaluated with standard reference materials, which were based on bovine liver or rice flour sample matrices. However, these matrices are a poor reference material for chocolate, which is rich in fats highly resistant to wet oxidation. So, these published methods necessitate filtration or centrifugation of the samples. The dry ashing procedure described here resulted in clear, residue-free samples, which gave reproducible copper values across all samples.

Table 1 shows the copper contents of 22 brands of chocolate. Many of the brands are marketed worldwide, while a few are products specific to the Swiss market. The lowest copper contents were found in two brands of white chocolate, which are not chocolates in the strict sense of the word, since they do not contain cocoa. They had copper contents of $0.11 \pm 0.05$ and $1.02 \pm 0.13 \mu \mathrm{g} / \mathrm{g}$. For the cocoa-containing chocolate brands, the copper values ranged from $1.85 \pm 0.10$ to $16.50 \pm 1.29 \mu \mathrm{g} / \mathrm{g}$. Interestingly, there was a very good, linear correlation between the cocoa content and the copper content of chocolate brands $\left(R^{2}=0.89\right)$, without any dramatic outliers (Fig. 1). This suggests that the copper content of chocolate originates largely from the cocoa. This is also supported by the two white "chocolates", which did not contain cocoa and exhibited the lowest copper contents. Thus, the value of chocolate as a source of dietary copper directly depends on the cocoa content: Chocolates with a high cocoa content are a better source of dietary copper than those with a low content.

\section{Discussion}

The copper content of chocolate has not systematically been addressed in the scientific literature. Although a number of reports deal with the copper content of chocolate and other cocoa products such as chocolate drinks, cakes, etc., chocolate brands and cocoa contents were not given [8, 9, 12-16]. We thus saw a need to assess the copper content of specific chocolate brands and relate them to the cocoa content.

We here determined the copper content of 22 different chocolates, many of which find worldwide distribution today. There was a linear correlation between the cocoa content of these chocolates and the copper content, which ranged from $1.85 \pm 0.10 \mu \mathrm{g} / \mathrm{g}$ of a chocolate containing $31 \%$ cocoa to $16.50 \pm 1.29 \mu \mathrm{g} / \mathrm{g}$ of a chocolate with $85 \%$ cocoa. This clearly suggests that the copper is contributed by the cocoa. Indeed, cocoa beans are high in copper. The copper content of fermented cocoa beans from Ghana was reported to range from 88 to $173 \mu \mathrm{g} / \mathrm{g}$, depending on the length of pod storage [17]. How storage could affect the copper content is hard to perceive and may reflect a methodological problem. The copper content of cocoa powder from local markets in Greece, Pakistan, and Brazil ranged from 27 to $52 \mu \mathrm{g} / \mathrm{g}$ [12, 18, 19]. Hernandez et al. [20] analyzed the copper, zinc, manganese, iron, and magnesium content of primary chocolate mass from different 
Table 1 Copper and cocoa content of different chocolate brands a STD, standard deviation based on at least three measurements

\begin{tabular}{|c|c|c|c|c|}
\hline Nr. & Chocolate brand & $\operatorname{Cocoa}(\%)$ & $\mathrm{Cu}(\mu \mathrm{g} / \mathrm{g})$ & $\operatorname{STD}^{\mathrm{a}}(\mu \mathrm{g} / \mathrm{g})$ \\
\hline 1 & Lindt Excellence & 70 & 12.14 & 1.04 \\
\hline 2 & Cailler Frigor Black & 46 & 5.78 & 0.36 \\
\hline 3 & Cailler Frigor Milk & 36 & 4.20 & 0.08 \\
\hline 4 & Lindt Excellence Prodigieux & 90 & 15.28 & 1.17 \\
\hline 5 & Lindt Cresta Classic & 30 & 2.64 & 0.13 \\
\hline 6 & Cailler Crémant Intense & 64 & 10.80 & 0.47 \\
\hline 7 & Toblerone, legendary triangular chocolate & 28 & 2.47 & 0.03 \\
\hline 8 & Lindt Excellence Puissant & 85 & 16.50 & 1.29 \\
\hline 9 & Coop Prix Garantie chocolate with milk & 30 & 2.42 & 0.10 \\
\hline 10 & Frey Giandor Noir & 44 & 5.05 & 0.09 \\
\hline 11 & Coop Qualité \& Prix Milk & 31 & 1.85 & 0.10 \\
\hline 12 & Frey Milk Extra & 31 & 2.37 & 0.10 \\
\hline 13 & Coop Qualité \& Prix Les Classiques Crémant & 60 & 7.51 & 0.39 \\
\hline 14 & Frey Noir Special & 72 & 9.84 & 0.29 \\
\hline 15 & Criollo $1^{\mathrm{er}}$ Cru Orinoco & 72 & 9.67 & 0.60 \\
\hline 16 & MBudget chocolate white & 0 & 0.11 & 0.05 \\
\hline 17 & Wander Ovomaltine noir (Ovaltine) & 60 & 6.91 & 0.47 \\
\hline 18 & MBudget milk chocolate & 30 & 2.23 & 0.13 \\
\hline 19 & Suchard Marzipan & 18 & 2.50 & 0.07 \\
\hline 20 & Frey Giandor milk chocolate with almond cream & 37 & 3.58 & 0.30 \\
\hline 21 & Camille Bloch Torino & 34 & 3.19 & 0.44 \\
\hline 22 & Frey Giandor White & 0 & 1.02 & 0.13 \\
\hline
\end{tabular}

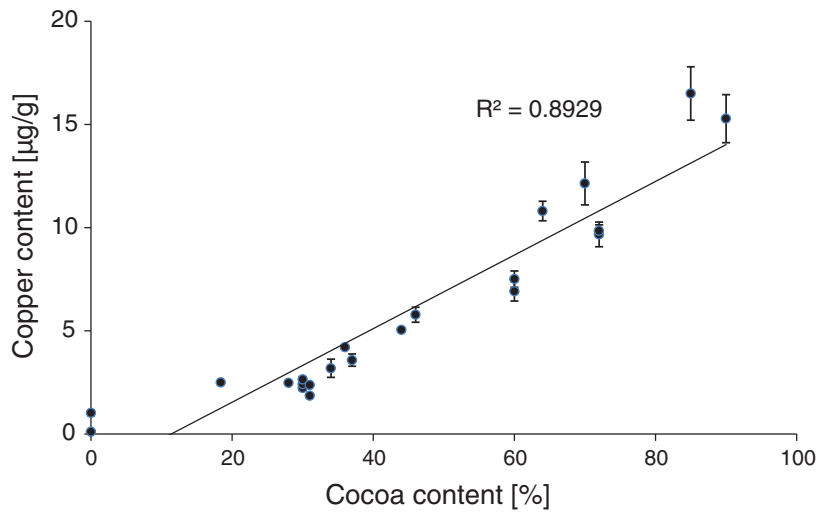

Fig. 1 Relationship of copper content and cocoa content of chocolate. The copper content of 22 brands of chocolate was plotted against the cocoa content. The error bars show the standard deviations of at least three independent measurements. The linear regression exhibited a correlation of $R^{2}=0.89$

manufacturers and found copper to vary between 11 and $27 \mu \mathrm{g} / \mathrm{g}$. They concluded that the metal contents depended on both, the origin of the cocoa beans and the grinding and milling process, necessary to obtain a smooth chocolate texture. Grinding and milling involves heavy equipment and extended contact times of the cocoa mass with various metal alloys. This can of course lead to enrichment of the cocoa with metal ions. Raw cocoa beans from plantations in Nigeria had a copper contents ranging from 104 to $642 \mu \mathrm{g} / \mathrm{g}$ [21]. According to the authors, the higher copper contents were due to the use of copper sulfate for disease prevention on these plantations. Clearly, cocoa in various forms has an intrinsically high copper content. It would be interesting to know how this relates to cocoa species, origin, and growth conditions. However, in today's global markets, it has become impossible to track the origin and species of the cocoa beans and chocolate producers are unwilling or probably even unable to provide corresponding information.

A majority of chocolates on the market have a cocoa content in the range of 30-60\% and thus an average copper content of around $4 \mu \mathrm{g} / \mathrm{g}$. A typical $100 \mathrm{~g}$ bar of chocolate thus contains $400 \mu \mathrm{g}$ of copper and would contribute $44 \%$ of the daily DRI for adults. On the other hand, $50 \mathrm{~g}$ of chocolate high in cocoa would contribute $100 \%$ of the DRI for copper. In contrast to the copper content, the caloric value of chocolate does not differ much between brands and is around $5 \mathrm{kcal} / \mathrm{g}(21 \mathrm{~kJ} / \mathrm{g})$. If chocolate is considered as a copper source, preference should clearly be given to brands with a high cocoa and thus a high copper content to minimize fat and energy intake.

According to an analysis of the eating habits of the elderly in the USA in 2000, chocolate contributed only $12 \%$ to the individual copper consumption [22]. This implies the consumption of 5-40 g/day of chocolate, 
depending on the cocoa content. Chocolate is clearly a good source of copper, and cocoa powder has successfully been used to combat copper deficiency associated with tube feeding in Japan [23]. Nevertheless, better sources for extra copper would be beef liver or oysters, of which 5-15 g would suffice to provide the DRI and would be accompanied by a lower fat and energy intake.

Chocolate contains several biologically active constituents such as methylxanthines, biogenic amines, and cannabinoid-like fatty acids, all of which are potentially addictive substances. Indeed, excessive craving for chocolate is a well-known phenomenon [25]. In addition, chocolate has also been advocated as an antioxidant nutrient for cardiovascular health [26]. These aspects are beyond the realm of this discussion, but it should be noted that, aside of its value as a copper source, chocolate remains a highly interesting and enigmatic component of the human diet and clearly deserves further research.

Acknowledgments This work was supported by Grant CR32I3E-136073 from the Swiss National Science Foundation and a Russian Federation Government Grant to leading scientists.

\section{Conflict of interest None.}

Compliance with Ethics Requirements This article does not contain any studies with human or animal subjects.

\section{References}

1. National Research Council (2001) Dietary reference intakes for vitamin $\mathrm{A}$, vitamin $\mathrm{K}$, arsenic, boron, chromium, copper, iodine, iron, manganese, molybdenum, nickel, silicon, vanadium, and zinc. The National Academies Press, Washington

2. Rojas-Sobarzo L, Olivares M, Brito A, Suazo M, Araya M, Pizarro F (2013) Copper supplementation at $8 \mathrm{mg}$ neither affects circulating lipids nor liver function in apparently healthy Chilean men. Biol Trace Elem Res 156:1-4

3. Khouzam RB, Pohl P, Lobinski R (2011) Bioaccessibility of essential elements from white cheese, bread, fruit and vegetables. Talanta 86:425-428

4. Gletsu-Miller N, Wright BN (2013) Mineral malnutrition following bariatric surgery. Adv Nutr 4:506-517

5. Klevay LM (2011) Is the Western diet adequate in copper? J Trace Elem Med Biol 25:204-212

6. Stern BR (2010) Essentiality and toxicity in copper health risk assessment: overview, update and regulatory considerations. J Toxicol Environ Health A 73:114-127

7. Roman VB, Ribas BL, Ngo J, Gurinovic M, Novakovic R, Cavelaars A et al (2011) Projected prevalence of inadequate nutrient intakes in Europe. Ann Nutr Metab 59:84-95

8. Joo S-J, Betts NM (1996) Copper intakes and consumption patterns of chocolate foods as sources of copper for individuals in the 1987-88 nationwide food consumption survey. Nutr Res $16: 41-52$

9. Pennington JAT, Schoen SA, Salmon GD, Young B, Johnson RD, Marts RW (1995) Composition of core foods in the U.S. food supply, 1982-1991. J Food Compost Anal 8:171-217

10. Lindow CW, Elvehjem CA, Peterson WH (1929) The copper content of plant and animal foods. J Biol Chem 82:465-471

11. Güldas M (2008) Comparison of digestion methods and trace elements determination in chocolates with pistachio using atomic absorption spectrometry. J Food Nutr Res 47:92-99

12. dos Santos WNL, da Silva EGP, Fernandes MS, Araujo RGO, Costa ACS, Vale MGR et al (2005) Determination of copper in powdered chocolate samples by slurry-sampling flame atomicabsorption spectrometry. Anal Bioanal Chem 382:1099-1102

13. Ferreira HS, Santos AC, Portugal LA, Costa AC, Miro M, Ferreira SL (2008) Pre-concentration procedure for determination of copper and zinc in food samples by sequential multi-element flame atomic absorption spectrometry. Talanta 77:73-76

14. Knezevic G (1980) Schwermetalle in Lebensmitteln. Über den Kupfergehalt in Rohkakao, Kakao-, Halb- und -Fertigprodukten. Zucker- Süssw Wirtsch 33:75-77

15. Lee CK, Low KS (1985) Determination of cadmium, lead, copper and arsenic in raw cocoa, semifinished and finished chocolate products. Pertanika 8:243-248

16. Güldas M, Dagdelen AF, Biricik GF (2008) Determination and comparison of some trace elements in different chocolate types produced in Turkey. J Food Agric Environ 6:90-94

17. Afoakwa EO, Quao J, Takrama J, Budu AS, Saalia FK (2013) Chemical composition and physical quality characteristics of Ghanaian cocoa beans as affected by pulp pre-conditioning and fermentation. J Food Sci Technol 50:1097-1105

18. Anthemidis AN, Pliatsika VG (2005) On-line slurry formation and nebulization for inductively coupled plasma atomic emission spectrometry. Multi-element analysis of cocoa and coffee powder samples. J Anal Atom Spectrom 20:1280-1286

19. Ahmed I, Zaidi SSH, Khan ZA (1989) The determination of major, minor and trace elements in tea, tea liquor, instant coffee and cocoa samples. Pak J Sci Ind Res 32:513-516

20. Hernandez C, Bermond A, Ducauze CJ (1994) Discrimination de masses de cacao par l'utilisation de données chimiométriques: détermination de leur origine géographique et de leur traiement technologique à partir des teneurs en cations métalliques. Analusis 22:15-22

21. Adeyeye EI, Arogundade LA, Asaolu SS, Olaofe O (2006) Fungicide-derived copper content in soil and vegetation component, Owena cocoa (Theobroma cacao L.) plantations in Nigeria. Bangladesh J Sci Ind Res 41:129-140

22. Ma J, Betts NM (2000) Zinc and copper intakes and their major food sources for older adults in the 1994-96 continuing survey of food intakes by individuals (CSFII). J Nutr 130:2838-2843

23. Tokuda Y, Kashima M, Kayo M, Nakazato N, Stein GH (2006) Cocoa supplementation for copper deficiency associated with tube feeding nutrition. Intern Med 45:1079-1085

24. Johncilla M, Mitchell KA (2011) Pathology of the liver in copper overload. Semin Liver Dis 31:239-244

25. Bruinsma K, Taren DL (1999) Chocolate: food or drug? J Am Diet Assoc 99:1249-1256

26. Klevay LM (2012) Copper in chocolate may improve health. Clin Nutr 31:149 